\title{
PERAN DAN TANGGUNG JAWAB HAKIM WASMAT TERKAIT PERLINDUNGAN HAK-HAK NARAPIDANA DALAM LEMBAGA PEMASYARAKATAN
}

\author{
Oleh: Dwi Afrimetty Timoera*
}

\begin{abstract}
The purpose of this study was to determine how judges Wasmat role in protecting the rights of prisoners in the prison. The method used is a qualitative approach. The results showed that the Judge Wasmat ineffective in doing their jobs. Look at all them in performing their duties only as a mere formality. The main constraint is; First, they not only served as a Judge Wasmat but also as a judge on the Court. Second, the implementation of the tasks Judge Wasmat only set in the Code of Criminal Procedure, but its existence is not considered important between Attorney and Penitentiary Institutions. Third, the distance from the court to prison far enough. Fourth, lack of adequate facilities so as to make the work Wasmat Judges can not run properly.
\end{abstract}

Key Words: Prisoners, prisoners development, supervisor and observer judge

\section{PENDAHULUAN}

\section{A. Latar Belakang Masalah}

Penegakan hukum pidana merupakan sebagian dari penegakan hukum (di dalam sistem hukum). Penegakan hukum pidana dilakukan melalui sistem peradilan pidana. Melalui sistem peradilan pidana diusahakan penanggulangan dan pencegahan terhadap kejahatan yang terjadi di dalam masyarakat. Hakim adalah pejabat peradilan negara yang mempunyai wewenang untuk memeriksa dan mengadili semua perkara yang wilayah hukumnya meliputi daerah kekuasaannya (kompetensi absolut). Dalam memeriksa dan mengadili suatu perkara, hakim harus memperhatikan nilai-nilai yang berkembang di dalam masyarakat. Dalam hal ini, hakim sebagai pejabat peradilan yang independen diharapkan dapat memberikan keadilan kepada semua pihak. Memeriksa dan mengadili suatu perkara merupakan tugas pokok hakim yang kesemuanya itu di atur dalam undang-undang.

Di dalam penegakan hukum pidana ini dikenal adanya lembaga "Hakim Pengawas dan Pengamat" (selanjutnya disingkat dengan "Hakim Wasmat"). Undang-Undang No. 8 Tahun 1981 tentang Hukum Acara Pidana (dikenal juga dengan istilah Kitab Undang-Undang Hukum Acara Pidana dan disingkat dengan KUHAP) mengatur lembaga ini dalam suatu Bab sendiri yaitu Bab XX (Pasal 277 s/d 283) tentang Pengawasan dan Pengamatan Pelaksanaan Putusan Pengadilan (Reksodiputro 2007:59).

\footnotetext{
* Dosen Program Studi Pendidikan Pancasila dan Kewarganegaraan, Jurusan Ilmu Sosial Politik Fakultas Ilmu Sosial
} Universitas Negeri Jakarta 
Hakim Wasmat ini mengawasi dan mengamati pelaksanaan putusan Pengadilan.

$$
\text { Adanya pengawasan dan }
$$
pengamatan terhadap putusan pidana dari Pengadilan, menunjukkan bahwa Hakim tidak berhenti bertugas setelah putusan dijatuhkan, namun dia masih tetap bertugas setelah putusan dijatuhkan. Hakim yang aktif dalam proses peradilan pidana bukan hanya terhadap pemeriksaan pendahuluan (Praperadilan) dan di sidang Pengadilan, tetapi juga aktif sesudah putusan dijatuhkan oleh Pengadilan (Loqman 1996:125).

Ide pembentukan Lembaga Hakim Pengawas dan Pengamat ini sebenarnya sudah pernah dicetuskan oleh Oemar Seno Adji sekitar tahun 1972 yang merupakan adaptasi dari Lembaga Judge de I'aplication des peines atau sering disingkat dengan "j.a.p" yang dikenal di Prancis pada tahun 1959. Di Prancis, "Judge de I'aplication des peines" ini baru dapat menjalankan tugasnya setelah putusan dijatuhkan, bahkan sesudah orang yang dipidana itu keluar dari Lembaga Pemasyarakatan, sementara peranannya juga hanya sebatas melakukan pengawasan dan pengamatan dalam Lembaga Pemasyarakatan maupun terhadap pelepasan bersyarat.
Pengawasan dan pengamatan yang dilakukan Pengadilan menghendaki Hakim selalu mengikuti terpidana atau narapidana. Di mana sebagai pelaksana putusan pidana Pengadilan adalah Jaksa dan tempat pelaksanaannya adalah di dalam Lembaga Pemasyarakatan. Peran Hakim Pengawas dan Pengamat untuk mengadakan pengawasan dan pengamatan menempatkannya sebagai pengontrol pelaksanaan putusan pengadilan sebagaimana diatur dalam KUHAP maupun dalam Surat Edaran Mahkamah Agung RI No.7 Tahun 1985. Inti dari tugas pengawasan dan pengamatan adalah hakim harus aktif menjaga agar tidak terjadi pelanggaran terhadap hak-hak terpidana yang memperoleh putusan pidana penjara. Pada saat hakim menjalankan pengawasan dan pengamatan, selalu mengadakan kontak secara langsung dengan petugas Lembaga Pemasyarakatan maupun dengan terpidana sehingga dapat langsung memberikan koreksi jika diketahui terdapat pelanggaran Hak Asasi Manusia yang menyebabkan penderitaan atau merendahkan martabat narapidana sebagai seorang manusia. 


\section{B. Pembatasan Masalah}

Berdasarkan uraian latar belakang, maka dapat dikemukakan beberapa rumusan permasalahan dalam tesis ini sebagai berikut:

1. Bagaimana peran dan tanggung jawab Hakim Wasmat terkait dengan perlindungan hak- hak Narapidana dalam Lembaga Pemasyarakatan?

2. Bagaimana implementasi pengawasan Hakim Wasmat terhadap Kejaksaan dan pengamatan terhadap Lembaga Pemasyarakatan dalam pelaksanaan putusan pengadilan?

3. Apa yang menjadi faktor penghambat implementasi tugas Hakim Wasmat serta upaya apa yang dilakukan untuk mengatasinya?

\section{Tujuan Penelitian}

Tujuan utama dalam penelitian ini, yaitu: (a) untuk mengetahui apakah hakhak narapidana diterima dengan baik atau tidaka di lembaga pemasyarakatanun; (b) untuk mengetahui bagaimana mekanisme hakim Wasmat dalam mengawasi pelaksanaan hak-hak narapidana pada saat di lembaga pemasyarakan.

\section{Manfaat Penelitian}

Terlaksananya penelitian ini supaya dapat diketahuinya bagaimana pembinaan narapidana dalam lembaga pemasyarakatan yang dalam pelaksanaannya diawasi dan diamati oleh seorang hakim yang ditugasi untuk itu. Selain itu, penelitian ini dapat dijadikan penelitian rujukan bagi mereka yang ingin melaksanakan penelitian dengan tema yang sama.

\section{E. STUDI PUSTAKA}

Orang yang melakukan tindak pidana dan melanggar aturan pidana, di negara hukum, maka dia akan dijatuhi hukuman kalau memang terbukti melakukan kesalahan dan ada aturan yang mengaturnya. Istilah "hukuman " yang mereka terima berasal dari kata "straf" dan istilah "dihukum" yang berasal dari perkataan "Wordt gestraf" (Priyatno 2006:5). Hukuman yang mereka terima tersebut merupakan ganjaran dari perbuatan yang telah mereka lakukan, melalui proses-proses peradilan yang kemudian dijatuhi vonis oleh hakim. Ada beberapa instrumen utama yang biasa dijadikan pedoman kuat untuk menghukum pihak terpidana yang diduga terlibat pada berbagai kasus yng telah diputuskan bersalah, salah satunya adalah pidana penjara. Pemidanaan pada hakikatnya adalah mengasingkan narapidana dari lingkungan masyarakat serta sebagai salah satu upaya penjeraan (Panjaitan dan Chairijah 2008:30).

Masalah pemidanaan terutama pidana penjara ini telah berkembang sejalan dengan perkembangan masyarakat 
dari abad ke abad dan keberadaannya telah banyak diperdebatkan oleh para ahli (Sujatno 2008:6). Dimana dalam perdebatan itu, tidak semua sarjana berpendapat bahwa pidana pada hakikatnya adalah suatu penderitaan atau nestapa. Kita lihat pendapat dari Hulsman, dia mengatakan bahwa hakikat pidana adalah "menyerukan untuk tertib". Selanjutnya dia mengatakan hakikat pidana mempunyai 2(dua) tujuan utama yakni untuk mempengaruhi tingkah laku dan penyelesaian konflik. Begitu juga GP Hoefnagels tidak setuju dengan pendapat bahwa pidana merupakan suatu penjeraan. Dia melihat secara empiris bahwa pidana merupakan susatu proses waktu. Dimana proses itu dimulai dari penahanan sampai vonis dijatuhkan hakim itu sudah merupakan pidana (Sujatno 2008:8).

\section{Mardjono Reksodiputro} mengatakan, "menjalani pidana bukan untuk mencabut hak-hak asasi yang melekat pada dirinya sebagai manusia. Karena itu perlindungan yanng diberikan KUHAP (UU RI No.8 Tahun 1981) terhadap harkat dan martabat manusia, tetap mengikat terpidana juga ke dalam penjara." Variasi perdebatan para ahli mengenai pidana, terutama pidana penjara dan pelaksanaannya bukan saja pada pertanyaan "Apa", "Mengapa",dan "Bagaimana seharusnya", akan tetapi juga pertanyaan tentang "Apa hakekat"nya.
Sejauh ini, pertanyaan-pertanyaan di atas dijawab oleh para pakar dan ketentuan-ketentuannya dirumuskan dalam Kitab Undang-Undang Hukum Pidana Common Law System. Padahal Rene David menyebut bahwa ada sistem hukum pidana lainnya di dunia, yaitu hukum pidana dari negara-negara Asia Timur dan hukum pidana adat serta hukum yang bersumber dari agama. Matthew Lippman, Sean Me Coville dan Mardechai Yerusnalmi berpendapat bahwa Commmon Law, Civil Law dan Islamic Law merupakan tradisi hukum yang utama pada saat ini mencakup kegiatan-kegiatan hukum da filosofi dari mayoritas bangsabangsa di dunia.

Dr. Murrad Hofman seorang muslim Jerman dalam bukunya Islam The Alternative menulis bahwa para pakar hukum semestinya tidak mendapat kesulitan untuk setuju pada tiga legal sistem yang palin penting, Roman Law, Anglo Saxon, dan Islamic Law. Dalam hukum Islam, pidana penjara (kurungan) termasuk dalam kelompok pidana ta'zir. Artinya pidana yang merupakan kewenangan hakim untuk menentukannya. Arti pidana yang merupakan kewenangan hakim untuk menentukannya. Karena putusan perkaranya harus diselesaikan oleh Pengadilan yang dipimpin oleh seorang hakim. 
Dalam sejarah perkembangan hukum Islam, jenis pidana penjara telah dipraktekkan sejak masa Nabi Muhammad S.A.W. para sahabat dan generasi penerusnya. Sejalan dengan tujuan pemidanaan dalam hukum Islam yang intinya untuk memelihara agama (hifz aldin), memelihara akal (hifz al-aql), memelihara jiwa (hifz al-ruh) da memelihara harta (hifz al-mal), serta memelihara ketturunan agar pelaku tindak pidana mendapat pelajaran, menyadari kesalahan, memperbaiki diri dan kembali menjadi manusia yang baik. Konsep ini sejalan dengan konsep taubat. Menurut ajaran Islam taubat merupakan satusatunya cara bagi manusia untuk membersihkan diri dari berbagai bentuk kesalahan dan dosa dan melepaskannya dari kecemasan yang mengguncangkan jiwa. Taubat dalam pandangan Islam harus dilakukan segera dan diiringi dengan tekad untuk tidak mmengulangi kesalahankesalahan yang telah diperbuat. Kesungguhan dalam bertaubat harus dibuktikan dalam bentuk melaksanakan perbuatan-perbuatan baik. Essensi taaubah dalam kkonsep hhukum Islam yang terkait dengan pemidanaan penjara, sejalan dengan konsep pemidanaan dalam Sistem Pemasyarakatan di Indonesia (Sujatno 2008:8).
Di mana dalam sistem pemasyarakatan di Indonesia, setelah hakim menjatuhkan vonisnya, maka pelaksanaan putusan hakim tersebut yang berupa putusan hukuman penjara, dilaksanakan di lembaga pemasyarakatan. Karena pada saat kita membicarakan Sistem Peradilan Pidana Terpadu, kita tidak hanya tertuju pada lembaga pengadilan saja, tetapi semua lembaga yang memiliki kekuasaan di bidang penegakkan hukum yakni Kepolisian, Kejaksaan, dan juga Lembaga Pemasyarakatan sebagai pelaksana putusan atau penetapan hakim tersebut.

Sistem Pemasyarakatan Narapidana di Indonesia, secara tepat menggariskan (yang dikutip SEMA 7/1985) bahwa pemidanaan tidak dimaksudkan untuk menderitakan dan tidak diperkenankan merendahkan martabat manusia. Karena itu itu peran hakim Wasmat adalah menjaga agar perlakuan terhadap narapidana tidak menyalahi asas tersebut. Hak-hak narapidana tersebut yang perlu mendapat perlindungan antara lain :

1. Dalam hal hukuman disiplin, tidak diperkenankan hukuman badan yang bersifat penyiksaa, baik fisik ( pemukulan, pencambukan, dirantai, dijemur dibawah sinar matahari yang terik, dans ebagainya) maupun psikis (disekap sendiri berhari-hari dalam sel yang sempit dan pengab, mencabut 


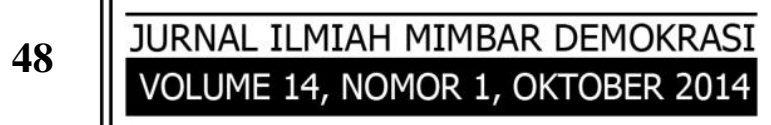

haknya menerima surat dan kunjungannya secara tidak wajar, dan sebagainya).

2. Dalam penyiksaan, penganiayaaan atau prilaku melanggar kesusilaan dari sesama narapidana

3. Dalam hal perawatan medis, kalau narapidana itu sakit maka dia harus mendapatkan pelayanan medis yang baik

4. Dalam hal melakukan kegiatan keagamaan

5. Dalam hal berhubunngann dengan masyarakat diluar Lembaga Pemasyarakatan

6. Dalam hak hak lain yang dibenarkan oleh peraturan yang berlaku sehubungan dengan tetap dihargainya martabat terpidana sebagai manusia (makan, minum, cara membersihkan diri, tempat untuk tidur, kesempataan rekrreasi, kesempatan bekerja, kesempatan menambah pengetahuan dan sebagainya).

Supaya hak-hak tersebut tidak dilanggar di dalam lembaga pemasyarakatan, baik oleh petugas lembaga itu sendiri, maupun oleh sesama narapidana, maka diperlukanlah sebuah pengamatan dan pengawasan yang dilakukan oleh seorang hakim yang dikenal dengan hakim Wasmat.

\section{METODE PENELITIAN}

Penulisan ini akan menggunakan metode penelitian deskriptif kualitatif. Jenis data yang akan digunakan dalam penelitian ini adalah data primer berupa wawancara, observasi dan atau kuesioner serta data sekunder berupa bahan hukum primer, sekunder dan tersier.

Penulis melakukan penelitian dengan menggunakan metode pendekatan kualitatif dengan tujuan agar penelitian hukum ini dilakukan berdasarkan faktafakta yang ditemui di lapangan.

\section{Sumber Data}

Data yang akan dikumpulkan dalam penelitian ini bersumber dari beberapa jenis data, yaitu:

\section{a) Data Primer}

Data yang diperoleh di lapangan dengan melakukan beberapa metode seperti observasi, wawancara atau menyebarkan kuesioner terhadap responden melaui pengajuan pertanyaan pertanyaan secara terstruktur.

\section{b) Data Sekunder}

Data ini dikumpulkan melalui penelitian kepustakaan yang didasarkan pada sumber sumber yang ada. Data sekunder ini diperoleh dari bahan-bahan hukum yang terdiri atas: 
Selain itu, untuk mendapatkan data yang lengkap dalam penelitian ini, maka teknik pengumpulan data yang dipergunakan adalah:

\section{a. Wawancara (Interview)}

Untuk mendapatkan data dan penjelasan yang akurat, maka penulis melakukan wawancara dengan para pihak yang dianggap kompeten memberukan keterangan mengenai objek yang diteliti. Pihak yang berkompeten ini antara lain Kejaksaan, petugas LP dan Hakim Wasmat.

\section{b. Studi Kepustakaan}

(Library Research)

Studi kepustakaan ini dilakukan dengan cara mempelajari dokumen-dokumen atau bahanbahan pustaka, seperti buku-buku, literatur-literatur dan jurnal ilmiah serta makalah seminar yang berhubungan dengan masalah yang diteliti.

\section{Analisis dan Pengolahan Data}

Data yang diperoleh dari penelitian akan dijabarkan untuk kemudian dianalisis sehingga menghasilkan laporan penelitian yang bersifat deskriptif analitis.

\section{HASIL PENELITIAN}

Adapun yang menjadi objek penelitian dari penulis adalah Rumah Tahana Negara (Rutan) Pondok Bambu yang berlokasi di Jalan Pahlawan Revolusi No. 38, Pondok Bambu Jakarta Timur. Rutan ini di dirikan pada tahun 1974 oleh Pemda DKI Jakarta. Pada awal didirikannya Rutan ini ditujukan bagi para pelanggar peraturan Perda seperti tuna susila, tuna wisma, gelandangan dan pengemis.

Berdasarkan Keputusan Menteri Kehakiman RI Nomor:M04.PR.07.03 Tahun 1985 tanggal 20 September 1985, bangunan tersebut dialih fungsikan sebagai rumah tahanan Negara Klas IIA yang fungsinya adalah tempat orang tahanan Negara yang diduga melakukan pelanggaran hukum. Rutan Pondok Bambu ini berdiri di atas tanah seluas lebih kurang 14.586 M2 persegi yang berstatus Hak Pinjam Pakai dari pemerintah DKI Jakarta, yang terdiri dari gedung perkantoran, perumahan dinas, garasi kendaraan, 5 paviliun hunian, 1 paviliun karantina dan 1 ruang isolasi.

Berdasarkan Keputusan Menteri Kehakiman RI Nomor:M.04-PR.07.03 Tahun 1985 Tentang Organisasi dan Tata Kerja Rumah Tahan Negara dan Rumah Penyimpanan Benda Siatan Negara, maka Rutan Pondok Bambu ini dipimpin oleh seorang Kepala yang membawahi 4 orang 
Kepala Bagian dan petugas Tata Usaha.

Pada awal berdirinya, Rutan Pondok Bambu ini memiliki kapasitas penghuni berkisar kurang lebih 504 orang. Tapi pada saat ini, kapasitas itu mencapai 619 orang karena adanya bangunan baru. Pada saat penulis melakukan penelitian, pada tanggal 9 Desember 2011, dari 619 orang tersebut, jumlah narapidana adalah 342 orang yang terdiri dari 53 orang narapidana laki-laki dan 289 orang narapidana perempuan. Mereka adalah orang-orang yang telah dijatuhi vonis Hakim. Sedangkan 277 orang lagi adalah mereka-mereka yang belum dijatuhi vonis Hakim atau masih dalam proses peradilan. Mereka-mereka yang berada disini biasanya akan ditempatkan di Lapas Wanita Tangerang, Lapas Anak dan Pemuda Tangerang, Lapas Wanita Bandung dan Lapas di Serang Banten.

Tapi apa yang diuraikan di atas, tidak ditemukan pada saat penulis melakukan penelitian lapangan. Padahal diketahui bahwa pada saat narapidana yang berada di Lembaga Pemasyarakatan atau dititipkan di Rutan, maka mereka punya hak-hak yang harus dipenuhi walaupun kemerdekaan mereka terampas. Supaya hak-hak mereka tersebut tidak terabaikan, maka diperlukanlah peran Hakim Wasmat untuk melihat dan melindungi hak-hak tersebut.
Dari hasil penelitian penulis di Rutan Pondok Bambu, Hakim Wasmat yang seharusnya berperan dan bertanggungjawab adalah Hakim dari 5 wilayah hukum Propinsi DKI Jakarta, dan wilayah hukum Bekasi. Dikatakan juga tidak semua Hakim Wasmat ini yang melaksanakan tugasnya sebagai Hakim Wasmat seperti Hakim Wasmat dari Wilayah hukum Pengadilan Jakarta Timur hanya berkunjung dalam setahun dua kali, Hakim Wasmat dari Wilayah Hukum Jakarta Utara tidak pernah sama sekali, dari Jakarta Pusat tiga kali dalam setahun, Bekasi sau kali dalam setahun, Jakarta Barat tidak pernah dan Jakarta Selatan dua kali dalam setahun. Padahal seharusnya Hakim Wasmat ini harus memberikan laporan kepada Ketua Pengadilan Negeri wwilyah hukum masing-masing setiap tiga kali sebulan.

Kalau dilihat peran dan tanggungjawab Hakim Wasmat ini tidak berjalan sebagaimana mestinya. Menurut pengakuan petugas Rutan, Hakim Wasmat tidak efektif dalam melakukan pekerjaannya. Terlihat sekali mereka dalam melakukan tugasnya hanya sebagai formalitas belaka. Hal ini dibuktikan juga pada saat Hakim Wasmat berkunjung ke Rutan Pondok Bambu yang hanya berada di ruangan Kantor Rutan dan tidak pernah mendatangi para Narapidana untuk menanyakan tentang hak-hak mereka. Ini 
juga dibuktikan pada saat penulis melakukan wawancara dengan beberapa narapidana yang berada di Rutan tersebut. Seperti apa yang dikatakan oleh Regita (narapidana Rutan Pondok Bambu) yang hampir satu tahun menghuni Rtan yang divonis oleh Hakim Pengadilan Negeri Jakarta Timur yang belum pernah didatangi oleh Hakim Wasmat untuk bertanya tentang hak yang dia terima atau tidak diterima. Hal serupa juga diutarakan oleh Wina, Angel, Siti Aminah, Subekti, Rafi, Ihsan, Adrian, Tedy dan Reza. Bahkan mereka juga tidak mengerti apa itu Hakim Wasmat. Pada saat penulis menjelaskan tentang Hakim Wasmat kepada mereka, mereka baru mengerti bahwa ada seorang Hakim yang bertugas dan bertanggungjawab terhadap hak-hak mereka sebagai seorang narapidana.

Berbeda dengan apa yang dikatakan oleh Ketua Pengadilan Negeri Jakarta Timur, bahwa Hakim Wasmat itu tugasnya sangat penting tetapi kendala yang mereka hadapi adalah mereka tidak hanya bertugas sebagai Hakim Wasmat tetapi juga sebagai Hakim yang akan bertindak dalam proses peradilan sehingga terlihat ada dua fungsi yang harus dilakukan oleh Hakim tersebut selain sebagai Hakim di Pengadilan tetapi juga sebagai Hakim Wasmat yang punya tanggungjawab untuk melakukan pengawasan dan pengamatan pelaksanaan hak-hak narapaidana di Lembaga
Pemasyarakatan.

Selain itu, Ketua Pengadilan Negeri Jakarta Timur juga mengatakan bahwa pelaksanaan tugas Hakim Wasmat ini hanya diatur di dalam KUHAP tetapi keberadaannya dianggap tidak penting diantara Lembaga Kejaksaan dan Lembaga Pemasyarakatan. Selain itu jugta jarak tempuh dari pengadilan ke Rutan atau Lapas tersebut juga jauh dan sarana prasarana juga tidak dilengkapi sehingga membuat kerja Hakim Wasmat ini tidak dapat berjalan dengan baik.

Gambaran mengenai kegagalan yang dapat terjadi dalam system peradilan pidana untuk mencapai tujuannya disebabkan oleh tidak sinkronnya setiap subsistem dalam melaksanakan peran dan tanggung jawabnya dengan tujuan system secara umum (Pandjaitan dan Widiarty 2008:7). Untuk itulah, keterpaduan dalam sistem peradilan pidana baik pada tahap pra-ajudikasi, ajudikasi maupun purna ajudikasi merupakan syarat utama. Mardjono Reksodiputro mengatakan bahwa dalam suatu sistem peradilan pidana yang terpadu (integrated ajudication) sama pentingnya dengan tahap-tahap terdahulunya, Walaupun masih tetap dianut bahwa tahap ajudikasi tahap "dominan" dalam seluruh proses (Pandjaitan dan Widiarty 2008:7). 
Proses baru berhenti pada saat terpidana dilepaskan kembali ke masyarakat karena telah penyelesaikan pidana yang telah dijatuhkan kepadanya oleh pengadilan, selanjutnya dikatakan bahwa sistem ini dianggap berhasil apabila sebagian besar dari laporan maupun keluhan masyarakat yang menjadi korban kejahatan dapat "diselesaikan" dengan diajukannya pelaku kejahatan ke sidang pengadilan dan diputuskan bersalah serta mendapat pidana. Sejalan dengan kinerja sistem peradilan pidana untuk meresosialisasi dan merehabilitasi terpidana, adalah relevan melihat ide Sahardjo yang merupakan pembaharu falsafah hukuman. Dalam hal ini, Sahardjo berharap narapidana menjadi rang baik, aktif dan produktif di masyarakat.

Dengan demikian, penegak hokum harus memiliki kesamaan pandangan yaitu memikirkan nasib tersangka dan/atau terdakwa dalam proses peradilan sampai menjalani pidana penjara, karena banyak orang salah duga seolah-olah program rehabilitasi pelaku tindak pidana baru dimulai sejak ia memasuki pintu gerbang Lembaga Pemasyarakatan atau bentukbentuk treatment of offenders, padahal apa yang direncanakan Lembaga Pemasyarakatan itu hanyalah salah satu daru sub sistem saja dari penyelenggaraan sistem peradilan pidana (Criminal Justice System) yang secara keseluruhan merupakan suatu sistem yang tidak dipikirkan sebagian demi sebagian, pengalamannya diinterogasi, ditahan caracara alat bukti dikumpulkan semuanya mempengaruhi tingkah laku narapidana terhadap penguasa dan faktor menentukan dalam penyesuaian terhadap program rehabilitasi. Seorang pelaku tindak pidana akan sampai pada tahap purna-ajudikasi setelah melalui tahap-tahap sebelumnya.

Dalam sistem peradilan pidana tugas utama hakim tidak berhenti setelah narapidana masuk ke Lembaga Pemasyarakatan atau bukan saja menjatuhkan hukuman, tetapi bertanggung jawab atas masa depan narapidana. Hakim sepatutnya menjelaskan kepada narapidana apa arti dan tujuan hukumannya maupun keberadaan Lapas. Dalam hal ini terdapat hubungan positif antara hakim dan Lembaga Pemasyarakatan untuk keberhasilan pembinaan narapidana. Dari hal di atas dapat dikatakan bahwa Lembaga Pemasyarakatan memberikan bahan kepada pengadilan negeri mengenai keberadaan narapidana melalui Hakim Wasmat yang sebelumnya (ada hakim Wasmat) pengadilan tidak mengetahui keberadaan dari narapidana. Sebagai konsekuensi logis dari putusannya yang melahirkan kesenjangan (gap) antara pengadilan dan lembaga pemasyarakatan sehingga dengan adanya Hakim Wasmat, kesenjangan tersebut dapat terjembatani. 
Menurut H. Umar Seno Adji diperlukan peran aktif Hakim Wasmat sejak pemeriksaan pendahuluan, pemeriksaan di persidangan dan sesudah putusan dijatuhkan dalam suatu proses pidana. Tidak saja hakim akan melihat akibat- akibat dari putusan yang dijatuhkan olehnya, melainkan ia memerlukan pemikiran-pemikiran mengenai cara yang sebaiknya untuk memasyarakatkan kembali si terhukum. Hakim Wasmat sangat terbatas kemampuannya untuk melakukan pengawasan dan pengamatan terhadap narapidana yang menjalani pembebasan bersyarat, oleh karena Hakim Wasmat jumlahnya sangat terbatas sementara beban kerja sebagai hakim di pengadilan negeri dirasa cukup banyak serta tidak adanya fasilitas yang memadai untuk melakukan pengawasan dan pengamatan bagi narapidana yang menjalani pembebasan bersyarat. Kerjasama antara Pengadilan dengan Kejaksaan yaitu, jelas tergambar bahwa pihak jaksa harus memberikan laporan kepada Pengadilan tentang telah dilaksanakannya putusan pengadilan.

Berdasarkan laporan tersebut selanjutnya Hakim Wasmat akan meneliti apakah hukuman telah dilaksanakan atau tidak, apakah Kejaksaan telah menjalankan pidana atau tidak, diteliti keberadaan narapidana yang telah dijatuhi pidana apakah benar-benar berada di Lembaga Pemasyarakatan, dan apabila dilakukan mutasi atau perpindahan narapidana maka harus dilaporkan pemutasian tersebut, sehingga dalam hal ini harus ada laporan dari Kejaksaan kepada Pengadilan. Ruang lingkup peran dan tanggung jawab Hakim Wasmat, hanya mencakup pelaksanaan putusan pengadilan oleh Jaksa dan petugas Lembaga Pemasyarakatan. Hal tersebut jelas jika kita beranjak dari pengaturan mengenai hakim Wasmat ini yang tertuang dalam KUHAP. Keaktifan Hakim Wasmat ditandai dengan kegiatan-kegiatan:

1) Menandatangani register pengawasan dan pengamatan

2) Mengadakan checking on the spot ke lapas untuk memeriksa kebenaran pelaksanaan putusan Pengadilan

3) Mengadakan observasi terhadap keadaan, suasana dan kegiatan-kegiatan yang berlangsung di dalam lingkungan tembok-tembok lembaga

4) Mengadakan wawancara dengan para petugas pemasyarakatan mengenai perilaku dan hasil-hasil pembinaan

5) Mengadakan wawancara langsung dengan para narapidana yang bersangkutan mengenai hal ikhwal pelaku terhadap dirinya.

6) Membuat laporan berdasarkan format yang telah tersedia dan dilaporkan kepada Ketua Pengadilan Negeri. 
Kewajiban pokok dari Hakim Wasmat dalam melakukan pengawasan terhadap pelaksanaan Putusan Pengadilan seperti yang ditetapkan Undang-undang Nomor 8 Tahun 1981 dan Surat Edaran Mahakamah Agung Republik Indonesia Nomor 7 Tahun 1985 diwujudkan dalam beberapa bentuk kegiatan yang Implementasinya dapat terlihat dari hasil penelitian akan kegiatan dimaksud seperti yang terurai di bawah ini :

1. Memeriksa dan Menandatangani Register Pengawasan dan Pengamatan Kegiatan ini dilakukan diawali setelah Pengadilan menjatuhkan hukuman kepada terpidana, maka tugas dan tanggung jawab Jaksa adalah mengeksekusi putusan tersebut. Artinya Jaksa-lah yang membawa dan menyerahkan tepidana ke Lembaga Pemasyarakatan dan oleh petugas Lembaga Pemasyarakatan terpidana tersebut ditempatkan ke dalam kamar sebagai tempat menjalani hukumannya kemudian dibuatlah Berita Acara Pelaksanaan Putusan Pengadilan (BA-8) yang ditandatangani oleh Jaksa Penuntut Umum, Kepala Lembaga Pemasyarakatan, dan terpidana yang bersangkutan, kemudian tembusan Berita Acara tersebut dikirimkan oleh Jaksa kepada Pengadilan dan Panitera mencatatnya dalam register Pengawasan dan Pengamatan.
2. Checking on the Spot

Undang-undang mengamanatkan kepada Hakim Wasmat untuk mengadakan cheking on the spot paling sedikit 3 (tiga) bulan sekali ke Lembaga Pemasyarakatan untuk memeriksa kebenaran berita acara pelaksanaan putusan pengadilan yang ditandatangani oleh Jaksa, Kepala Lembaga Pemasyarakatan dan terpidana ; apakah terpidana telah diserahkan oleh Jaksa ke pihak Lembaga Pemasyarakatan tepat pada waktunya dan apakah hukuman (pidana) yang dijatuhkan telah dilaksanakan secara nyata oleh Lembaga Pemasyarakatan; dan sebagainya. Untuk kegiatan ini, hasil penelitian menunjukkan bahwa Hakim Wasmat sudah melakukan checking on the spot ke Lembaga Pemasyarakatan seperti yang diperintahkan oleh Undang-undang. Bahkan kunjungan Hakim Wasmat dapat lebih sering dilakukan bila ada undangan dari pihak Lembaga Pemasyarakatan untuk mengikuti sidang Tim Pengamat Pemasyarakatan. Hasil wawancara dengan Hakim Wasmat yang ada mengatakan walaupun sibuk dengan tugas-tugas pokok akan tetapi melakukan kunjungan ke Lembaga Pemasyarakatan (checking on the spot) harus dilakukan, tetapi dengan jadwal yang diatur tersendiri oleh Hakim Wasmat dan tentunya disesuaikan dengan padatnya kegiatan seorang Hakim Wasmat yang juga sebagai Hakim peradilan umum. 


\section{Observasi}

Hakim Wasmat dalam mengadakan observasi atas keadaan, suasana dan kegiatan-kegiatan yang berlangsung dalam lingkungan tembok-tembok Lembaga Pemasyarakatan, khususnya untuk menilai apakah keadaan Lembaga Pemasyarakatan tersebut sudah memenuhi pengertian bahwa "pemidanaan tidak dimaksudkan untuk menderitakan dan tidak diperkenankan merendahkan martabat manusia", serta mengamati dengan mata kepala sendiri akan perilaku narapidana sehubungan dengan pidana yang dijatuhkan kepadanya. Menurut hasil penelitian di lapangan bahwa selama Hakim Wasmat mengunjungi Lembaga Pemasyarakatan, Observasi yang dilakukan atas keadaan suasana, dan bentuk-bentuk kegiatan yang dilakukan atas keadaan, suasana dan bentuk-bentuk kegiatan yang dilakukan di dalam tembok Lembaga Pemasyarakatan apakah pemidanaan tidak menderitakan dan merendahkan martabat manusia hasil pembinaan baik kemajuankemajuan yang diacapai maupun kemunduran-kemunduran yang terjadi dan sebagainya, seluruhnya dilaksanakan masih sebatas selayang pandang atau dengan kata lain masih selintas, hal ini disebabkan berbagai faktor antara lain jumlah penghuni (WBP)
Faktor Penghambat Implementasi Tugas Hakim Wasmat Terhadap

\section{Pembinaan Narapidana}

\section{Faktor hukum}

Menempatkan faktor peraturan hukum sebagai faktor penghambat dalam pelaksanaan tugas Hakim Wasmat adalah sangat realistis. Barangkali inilah yang digambarkan Satjipto Rahardjo sebagai "penyakit-penyakit yang melekat pada hukum". Keadaan ini juga telah mampu menarik perhatian beberapa pengkaji hukum, di antaranya Lon L. Fuller yang meminta perhatian akan perlunya memahami gejala patologis pada hukum; "bahwa orang akan dapat melakukan pemahaman terhadap hukum secara lebih baik, manakala ia juga secara sengaja mempelajari penyakit-penyakit hukum". Memperhatikan peraturan perundangundangan yang berkaitan dengan tugas Hakim Wasmat dalam mendukung pola pembinaan narapidana di Lembaga Pemasyarakatan, maka dapat dikatakan bahwa belum ada sinkronisasi di antara perundang-undangan yang ada. Dalam Bab XX KUHAP, Pasal 277 - 283 telah ditentukan mengenai prosedur (acara) pengawasan dan pengamatan pelaksanaan putusan pengadilan (perampasan kemerdekaan), demikian pula dalam S.E. MA No. 7 Tahun 1985 yang mengatur lebih lanjut mengenai ruang lingkup 
pengawasan dan pengamatan serta petunjuk teknis pelaksanaannya, namun ironisnya ketentuan mengenai hal tersebut tidak ditemukan dalam Undang-undang Pemasyarakatan sebagai UU yang menjadi dasar pembinaan narapidana di Lembaga Pemasyarakatan. Akibat tidak diaturnya Hakim Wasmat dalam UU Pemasyarakatan, maka tidak mengherankan lembaga Hakim Wasmat tersebut kurang bahkan tidak populer di kalangan Lapas.

\section{Faktor kelembagaan}

Kelembagaan Hakim Wasmat dan Lapas ataupun lembaga Kejaksaan sebagai mitra kerja pada kenyataannya kurang mendukung efektifnya pelaksanaan pengawasan dan pengamatan. Dalam hal terjadinya kelalaian dalam pelaksanaan putusan pengadilan oleh Jaksa dan Lapas secara kelembagaan ketiga institusi tersebut mempunyai tata organisasi tersendiri dan kedudukannya adalah sama, sehingga Hakim Wasmat tidak mempuyai kewenangan untuk menegur secara langsung, hanya sebatas menyampaikan surat kepada pimpinan instansi masingmasing. Selanjutnya secara kelembagaan pelaksanaan tugas Hakim Wasmat juga harus didukung oleh kualitas dan kuantitas Hakim Wasmat itu sendiri.
3. Faktor sarana dan prasarana

Memperhatikan sarana dan prasarana termasuk anggaran dan prasarana untuk menjamin terlaksananya tugas pengawasan dan pengamatan sebagai variabel sarana dan prasarana hukum, dijelaskan oleh Hakim Wasmat Pengadilan Negeri Jakarta, bahwa anggaran dan prasarana yang tersedia masih sangat kurang memadai. Dijelaskan lebih lanjut oleh Hakim Wasmat Pengadilan Negeri Jakarta, kurang memadainya anggaran dan prasarana menjadi salah satu faktor hambatan dalam implementasi tugas Hakim Wasmat dalam mengukung pola pembinaan narapidana

\section{KESIMPULAN}

Hakim adalah salah satu aparat penegak hokum yang punya fungsi dalam system peradilan pidana. Selain tugasnya adalah sebagai pemberi vonis diakhir proses peradilan pidana, hakim juga bertugas sebagai pengawas dan pengamat dalam pelaksnaann pembinaan narapidana dalam Lembaga Pemasyarakatan. Mulai terpidana itu berada dalam Lembaga Pemasyarakatan yang dibina di dalam Lembaga, sampai terpidana kembali kemasyarakatan, mulai dari asimilasi dalam tahap reintegrasi. Dalam penelitian ini penulis melihat :

Peran dan tanggung jawab hakim Wasmat terkait dalam perlindungan narapidana, 
sangat penting. Karena pada system peradilan pidana, tampak bahwa hakim Wasmat bisa menjembatani antara sub system kejaksaaan dan sub system pemasyarakatan. Dasar dari jembatan inilah yang diletakkan dalam tugas hakim Wasmat yang diatur dalam Bab XX KUHAP.

Implementasi dari peranan Hawasmat ini belum terlaksana dengan baik. Karena mengenai hakim Wasmat ini kedudukannya tidak terlalu penting. Aturan mengenai ini hanya ada di KUHAP, tetapi di dalam aturan- aturan Lembaga Pemasyarakatan dan aturan Kejaksaan tidak ada tentang hakim Wasmat ini. Ini menyebabkan tidak sinkronnya kinerja hakim Wasmat ini dengan kejaksaan dan Lembaga Pemasyarakatan. Karena dua lembaga lainnya tidak mau peranannya diawasi. Seperti jaksa sebagai Pembina narapidana tidak mau diatur oleh instansi lain apalgi oleh hakim Wasmat. Begitu juga denga lembaga pemasyarakatan. Karena mengenai hakim Wasmat ini tidak ada diatur secara jelas di aturan Kejaksaan dan aturan pemasyarakatan, hal ini yang menyebabkan hakim Wasmat tidak terlalu penting untuk mereka. Selain itu, yang menjadi hakim Wasmat ini adalah hakim yunior yg br diangkat, jadi tidak terlalu diperhatikan oleh kedua lembaga ini.

Yang menjadi faktor penghambat dari pelaksanaan tugas hakim Wasmat ini adalah, dimana tidak pedulinya lembaga pemasyarakatan dan kejaksaan terhadap keberadaan dan kewenangan yang ada pada hakim Wasmat ini. Hal ini dikarenakan tidak adanya aturan yang jelas selain KUHAP yang mengatur kewenangan dari pelaksanaan tugas dari hakim Wasmat ini.

\section{DAFTAR PUSTAKA}

\section{Sumber Buku}

Abdussalam, H.R., Tanggapan atas Rancangan Undang-undang tentang Hukum Acara Pidana Dept. Hukum dan HAM R.I., Jakarta: Restu Agung, 2008.

Adji, Oemar Seno, KUHAP Sekarang, Jakarta: Erlangga, 1985.

Atmasasmita, Romli, Strategi Pembinaan Pelanggar Hukum dalam Penegakan Hukum di Indonesia, Bandung: Alumni, 1982.

Dwidja Priyatno, Sistem Pelaksanaan $\begin{array}{lr}\text { Pidana Penjara } & D i \\ \text { Indonesia,Bandung; } & \text { Refika } \\ \text { Aditama, 2006. } & \end{array}$

Hamzah, Andi dan Rahayu, Siti, Suatu Tinjauan Ringkas Sistem Pemidanaan di Indonesia, Jakarta: Akademika Pressindo, 1983.

Karnasudirdja, H. Eddy Djunaedi, Beberapa Pedoman Pemidanaan dan Pengamatan Narapidana, Jakarta : Universitas Indonesia, 1983.

Loqman, Loebby, Hukum Acara Pidana Indonesia Suatu Ichtiar, Jakarta : Datacom, 1996

Reksodiputro, Mardjono, Hak Asasi Manusia Dalam Sistem Peradilan 
Pidana, Kumpulan Karangan Buku Ketiga, Jakarta: Pusat Pelayanan Keadilan dan Pengabdian Hukum d/n Lembaga Kriminologi UI, 1994.

Soemadipradja, Achmad R., dan Atmasasmita, Romli, Sistem Pemasyarakatan di Indonesia, Bandung: Bina Cipta, 1979

\section{Undang-Undang dan Peraturan Lainnya}

1. Undang-Undang Dasar 1945;

2. Undang-Undang Nomor 8 Tahun 1981 Tentang Hukum Acara Pidana

3. Undang-Undang Nomor 12 Tahun 1995 tentang Pemasyarakatan;

4. Undang-Undang Nomor 48 Tahun 2009 Tentang Kekuasaan Kehakiman;

5. Peraturan Pemerintah Nomor 31 Tahun 1999 Tentang Pembinaan dan Pembimbingan Warga Binaan Pemasyarakatan;

6. Peraturan Pemerintah Nomor 32 Tahun 1999 Tentang Syarat dan Tata Cara Pelaksanaan Hak Warga Binaan Pemasyarakatan;

7. Peraturan Pemerintah Nomor 28 Tahun 2006 Tentang Pembinaan dan Pembimbingan Warga Binaan Pemasyarakatan tentang Perubahan atas PP Nomor 32 Tahun 1999 tentang Syarat dan Tata Cara Pelaksanaan Hak Warga Binaan Pemasyarakatan;

8. Peraturan Pemerintah Nomor 57 Tahun 1999 Tentang Kerjasama Penyelenggaraan Pembinaan dan Pembimbingan Warga Binaan
Pemasyarakatan;

9. Surat Edaran Mahkamah Agung (SEMA) Nomor 7 Tahun 1985 Tentang Petunjuk Pelaksanaan Tugas Hakim Pengawas dan Pengamat

\section{Makalah , Tesis, Skripsi, dan Jurnal}

Gandasubrata, Purwoto S., "Peran dan Tanggung Jawab Hakim Pengawas dan Hakim Pengamat Terhadap Putusan Pidana Yang Dijatuhkan". 2001.

Sulistio, Kasiati, Peran Hakkim Pengawas Dan Pengamat Dalam Rangka Memberikan Perlindungan Hukum Terhadap Terpidana Anak, Skripsi, UI, 2008.

Thurman S.M. Hutapea, Thurman S.M., Peran Hakim Pengawas Dan Pengamat Terhadap Pola Pembinaan Narapidana Di Lembaga Pemasyarakatan Klas II B Siborongborong, Tesis, USU, 2009

\section{Sumber Internet}

http://berita.liputan6.com/daerah/201102/3 21918/Napi_Disiksa_Sipir_Hingga Kritis diakses pada tanggal 5 Maret 2011;

http://hukumonline.com/berita/baca/hol169 47/narapidana-mengeluh-hakmereka-sering-diabaikan, diakses pada tanggal 1 Maret 2011; 